Discussion Paper No. 02-05

\title{
The Adoption of Business-to-Business
}

E-Commerce:

\section{Empirical Evidence for German Companies}

Irene Bertschek and Helmut Fryges

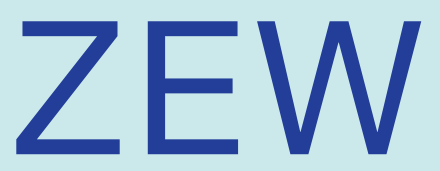

Zentrum für Europäische Wirtschaftsforschung GmbH

Centre for European

Economic Research 
Discussion Paper No. 02-05

\section{The Adoption of Business-to-Business E-Commerce: \\ Empirical Evidence for German Companies}

Irene Bertschek and Helmut Fryges

Download this ZEW Discussion Paper from our ftp server:

ftp://ftp.zew.de/pub/zew-docs/dp/dp0205.pdf

Die Discussion Papers dienen einer möglichst schnellen Verbreitung von neueren Forschungsarbeiten des ZEW. Die Beiträge liegen in alleiniger Verantwortung der Autoren und stellen nicht notwendigerweise die Meinung des ZEW dar.

Discussion Papers are intended to make results of ZEW research promptly available to other economists in order to encourage discussion and suggestions for revisions. The authors are solely responsible for the contents which do not necessarily represent the opinion of the ZEW. 


\section{Non-technical Summary}

The fast technological development of the Internet as well as the declining prices for the use of this technology have led to an increased diffusion of the Internet during the last few years. One important application of Internet technology for firms is so-called Internet commerce or electronic commerce. Although broadly discussed in the media and glorified as the most promising medium for ordering, buying and selling products and services, e-commerce is in fact still at the beginning of a diffusion process whereas e-commerce between companies (business-to-business or $\mathrm{B} 2 \mathrm{~B}$ ) currently has a broader scope than e-commerce between companies and consumers (business-to-consumers or B2C). Since B2B e-commerce can be regarded as a new technology (application) or a process innovation, this study attempts to evaluate several hypotheses proposed mainly in the literature on technology diffusion or adoption, but also in the innovation literature. The empirical analyses are based on a data set comprising 3,000 enterprises from the German manufacturing industry and the German services sector in the year 2000. We find positive and significant effects of firm size, the share of highly qualified employees and the export share. An IT-intensive production process, measured by the proportion of employees working predominantly at a PC, the share of ICT specialists as well as the use of Electronic Data Interchange, enhances the probability of a broad use of B2B e-commerce. An important influence on the use of $\mathrm{B} 2 \mathrm{~B}$ is the bandwagon effect, implying that firms are more likely to use this new Internet application if others within the same industry likewise do it. We find no significant effects of firm age and of the fact that a firm belongs to a group of companies as measures of a firm's flexibility and financial power. 


\title{
The Adoption of Business-to-Business E-Commerce: Empirical Evidence for German Companies $^{1}$
}

\author{
Irene BertscheK* and Helmut FRYGes**
}

January 2002

\begin{abstract}
Although in its infancy, one promising application of Internet technology for firms is so-called Internet commerce or electronic commerce. This paper analyses the determinants of B2B (business-to-business) adoption borrowing from the literature on the adoption of new technologies and considering factors like firm size, corporate status, human capital and international competitive situation. An ordered probit model is applied to a data set containing about 3,000 enterprises from the German manufacturing industry and the German services sector in the year 2000. We find positive and significant effects of firm size, the share of highly qualified employees and the export share. An IT-intensive production process enhances the probability of a broad use of B2B e-commerce. An important influence on the use of B2B is the bandwagon effect, implying that firms are more likely to use this new Internet application if others within the same industry likewise do it. We find no significant effects of firm age and of the fact that a firm belongs to a group of companies as measures of a firm's flexibility and financial power.
\end{abstract}

\footnotetext{
${ }^{1}$ Helpful suggestions by Horst Entorf, Avi Goldfarb as well as other participants of the ZEWconference on the 'Economics of Information and Communication Technologies', Mannheim, June 18-19, 2001, are gratefully acknowledged. We thank Ramona Hönicke and Friedhelm Sauer for competent research assistance.

${ }^{*}$ Corresponding author: Centre for European Economic Research, Research Group Information and Communication Technologies, P.O. Box 103443, D-68034 Mannheim, Germany, email: bertschek@zew.de.

${ }^{* *}$ Centre for European Economic Research, Department of Industrial Economics and International Management, P.O. Box 103443, D-68034 Mannheim, Germany, email: fryges@zew.de.
} 


\section{Introduction}

The fast technological development of the Internet as well as the declining prices for the use of this technology have led to an increased diffusion of the Internet during the last few years. As a recent survey conducted by ZEW revealed, in the year 2000 about $85 \%$ of all German companies had access to the Internet. TheOne important application of Internet technology for firms is so-called Internet commerce or electronic commerce. E-commerce is expected to reduce transaction costs, increase market transparency and make the course of business more efficient. Although broadly discussed in the media and glorified as the most promising medium for ordering, buying and selling products and services, e-commerce is in fact still at the beginning of a diffusion process whereas e-commerce between companies (business-to-business or B2B) currently has a broader scope than e-commerce between companies and consumers (business-to-consumers or B2C). OECD (1999, p.12), for example, claims that the $\mathrm{B} 2 \mathrm{~B}$ segment accounted at that time for at least $80 \%$ of total e-commerce sales.

Up to now there is not much empirical literature on B2B e-commerce. Based on the fact that $\mathrm{B} 2 \mathrm{~B}$ e-commerce can be regarded as a new technology or a process innovation, this study attempts to evaluate in a more or less explorative way several hypotheses proposed mainly in the literature on technology diffusion or adoption, but also in the innovation literature. For instance, the implementation of a new technology might depend on the size of the firm in the sense that larger firms are more likely to adopt a new technology due to the risks and costs involved with the adoption. As pointed out by Baptista (2000), the firm's corporate status as a measure of flexibility but also as an indicator of its financial power is likely to affect the adoption of a new technology. The (international) competitive situation a firm is faced with is likely to affect the firm's decision whether or not to use a process innovation or (see for example Bertschek, 1995). Moreover, the availability of qualified personnel might enable the adoption of B2B (Wozniak, 1987). The general openness towards new information and communication technologies or put in other words the IT-intensity of a firm is likely to affect the probability of using B2B. Last but not least, the so-called bandwagon effect (Jensen, 1982) claims that firms are more likely to use a new technology if others within the same industry likewise do it.

The empirical analysis is based on a data set containing about 3,000 firms from the German manufacturing and service industries surveyed in the year 2000. Ordered probit estimations reveal that the bandwagon effect represents an important aspect in determining the adoption of $\mathrm{B} 2 \mathrm{~B}$, implying that the higher the percentage share of firms already using this new Internet application, the higher the probability that an individual firm also uses B2B. Moreover, the firm size as well as the international 
competition have both positive and significant impacts. General openness to new information and communication technologies (ICTs) positively affects the adoption of B2B. On the other hand, firm age as well as affiliation to a group of firms as measures of a firm's flexibility and financial power turn out to be insignificant.

The paper is organized as follows: section two contains the main hypotheses on the adoption of a new technology derived from the literature. A description of the data set is given in section three. Section four presents the empirical results and section five concludes.

\section{Background Discussion}

Models of technology diffusion generally attempt to explain the share of firms adopting a new technology over time (so-called "epidemic models"). In these models, a sigmoid form of the diffusion path is usually assumed "indicating that a few firms adopt the invention early, that the adoption process accelerates as other firms learn about the invention and that the process decelerates when most firms have already adopted" (Tirole, 1988, p. 402). For recent and comprehensive surveys on models of diffusion, see Geroski (2000) and Karshenas and Stoneman (1995). ${ }^{2}$ Baptista (2000) investigates the diffusion of computer numerically controlled (CNC) machine tools and microprocessors, using data of about 1,000 firms covering six three-digit industrial sectors and ten regions of Great Britain for the time period 1968 to 1980. Using a hazard rate model, he finds that, especially at the early stage of diffusion, regional learning effects play an important role in the sense that they reduce the time of adoption. Gruber and Verboven (2001) analyse the diffusion of mobile telecommunications services in the 15 member states of the European Union for the period 1984 to 1997 using a logistic model of diffusion. They find that the transition from analogue to digital technology as well as the deregulation of the telecommunication market have positive effects on the diffusion of mobile telecommunications. This method of analysing diffusion processes, however, requires a comprehensive data base with observations starting at the phase of invention of the new technology.

As recent surveys have shown, e-commerce is still at the beginning of a diffusion process, see for example DIHT and mediamit (2000) on the diffusion of several ICTs in German companies, Gault (2000) on the diffusion of ICT in Canadian companies as well as OECD (1999). Therefore, the question arises which firms are the adopters of B2B e-commerce and what characteristics determine their decision to adopt B2B. Since this question can best be answered by analysing individual adoption decisions, the most commonly used approach found in literature is the probit model. In this

\footnotetext{
${ }^{2}$ For recent empirical analyses see for instance Baptista (2000) and Gruber and Verboven (2001).
} 
case, a firm's individual decision on whether or not to adopt B2B e-commerce can be studied in conjunction with diverse firm-specific and industry-specific characteristics. David (1969) and Davies (1979) provide early examples (see also Thirtle and Ruttan, 1994, p. 108-113 for an overview). David (1975) investigates the use of mechanical reapers. A farmer is supposed to adopt this technology if a farm's saving in wages due to the reduction in labor costs exceeds the costs of the reaper, which in turn heavily depends on firm size.

A firm's decision on whether or not to use B2B e-commerce depends on the (expected) net return associated with the use of B2B. This return is influenced by several factors. Mazon and Pereira (2001) assume the reduction of production costs by engaging in e-commerce (B2C or B2B). According to the recent work by LuckingReiley and Spulber (2001, p. 56), B2B e-commerce might have positive impacts on the productivity of an enterprise via four channels: efficiencies from automation of transactions, economic advantages of new market intermediaries, the consolidation of demand and supply through organized exchange, and changes in the extent of vertical integration of companies. The aspect of transaction costs is also studied by Garicano and Kaplan (2000).

The implementation of e-commerce involves several costs. First of all, the technical requirements have to be fulfilled. Moreover, the working process has to be reorganized in order to allow efficient use of the new technology. Depending on whether or not a company produces and distributes physical products, the logistics information system as well as the inventory system may have to be adapted accordingly in order to guarantee a more flexible distribution of products.

Since direct reduction of costs, or increased returns from using a new technology generally cannot be identified in a straightforward way, one might set up different hypotheses concerning the factors that are likely to influence the trade-off between the costs and benefits of B2B.

Firm size

First of all, the introduction of B2B is likely to depend on firm size in the sense that adoption is more probable the larger the firm, since, as stated by Davies (1979, p.20), "... the costs and risks of early adoption are more easily borne by large firms." Interpreting $\mathrm{B} 2 \mathrm{~B}$ as a process innovation allows the analysis of $\mathrm{B} 2 \mathrm{~B}$ to be embedded into the vast literature on innovative activity. In this case, one returns to the familiar Schumpeterian link between innovation and firm size, see for example Cohen and Levin (1989) for a not very recent but comprehensive study on the determinants of innovative activity.

Age of firm and corporate status

According to Christensen and Rosenbloom (1995), new firms are more flexible and thus more likely to adopt a new technology than old firms. The age of a firm is linked 
with firm size in the sense that large firms are generally old and young firms are generally small. As Baptista (2000, p.519) points out, the corporate status of a firm might play a role in affecting the adoption of a new technology. The independence of a firm might be involved with higher flexibility in deciding whether or not to adopt a new technology. However, firms that belong to a group of firms generally have more financial resources than others and thus might be less risk-averse in adopting a new technology.

\section{Availability of qualified personnel}

Wozniak (1987) analyses the impact of human capital, measured by education and experience, and of information, in the sense of the frequency of contacts with agricultural information sources, on the early adoption of a cattle feed additive monensin sodium and finds positive and significant effects of these components using crosssectional data of about 300 farmers in Iowa. In his model he assumes that a farmer maximizes his expected utility of income and he or she will adopt the new technology if the expected utility arising from the adoption of the new technology is larger than or equal to the expected utility in the case of sticking with the old technology. One hypothesis derived from this model is that uncertainty and fixed costs of adoption are hampering factors for the adoption of an innovation. However, education and experience might counteract these factors such that "... more educated and experienced farmers are more likely to be early adopters than other farmers" (Wozniak, 1987, p.104). His empirical results confirm this hypothesis.

\section{IT-intensity}

Another aspect that is not yet considered in the former literature, but that might be important in the context of using $\mathrm{B} 2 \mathrm{~B}$, is the firm's general openness to new information and communication technologies. This openness can be reflected by the share of ICT staff as a share of all employees or by the proportion of the firm's workforce predominantly working at a $\mathrm{PC}$ or a workstation. As regards electronic data interchange (EDI) as a precursor to B2B e-commerce, two possible effects may be assumed: Firms that already engage in EDI and are satisfied with this medium possibly do not need or want to change to B2B. Thus the expected effect of EDI on $\mathrm{B} 2 \mathrm{~B}$ is supposed to be negative. On the other hand, firms that are already familiar with EDI might be less apprehensive about adopting B2B, since they regard it as just another form of a business-to-business ordering system. In this case the impact of EDI on B2B is positive.

\section{International competitive pressure}

The adoption and intensity of use of a new technology might depend on the presence of international involvement. On the one hand, it seems plausible that companies engaged in foreign activities such as exports are more likely to use B2B e-commerce, 
since in this case the reduction of transaction costs is even higher than compared to transactions within the same country. This argument holds especially in the context of digital products. On the other hand, international competition forces domestic companies to produce as efficiently as possible in order to stay competitive. As Bertschek (1995) shows, international competition, measured as the share of imports and inward foreign direct investment to total domestic demand at the industrylevel, enhances the individual firm's probability of engaging in product or process innovation. These hypotheses are supported by empirical results based on a panel data set of roughly 1,200 firms from the German manufacturing industry. Since B2B e-commerce can be interpreted as a process innovation, the same arguments might hold in this context.

\section{Bandwagon hypothesis}

A commonly cited hypothesis in the context of technology adoption, the so-called bandwagon hypothesis, states that "... the probability of adoption by a firm at a given date is positively related to the proportion of firms in the industry who have already adopted" (see for instance Jensen 1982, p. 183). As Jensen states this assumption corresponds to Schumpeter's imitation hypothesis, implying that firms follow others in adopting a new technology if they have successful experiences with this technology.

\section{The Data}

The data results from a CATI-survey (computer-aided telephone interview) based on a stratified random sample of about 11,000 German firms. The sample was stratified by sector ${ }^{3}$, size class and region, i.e. West and East Germany. Only firms with at least five employees were included in the survey, thereof $50 \%$ in the manufacturing industry and $50 \%$ in the service sector. The source data set originates from Creditreform, the largest German credit rating agency. ${ }^{4}$ The survey was conducted in the year 2000. About 4,400 enterprises participated in the survey, which corresponds to a response rate of approximately $43 \%$. After performing consistency checks and due to item non-response concerning the variables that were included in the empirical model (see below), a sample of 3,026 firms forms the basis for the empirical analysis.

To operationalize the firms' involvement in electronic commerce, firms have been asked whether they use the Internet for distributing products and/or services to

\footnotetext{
${ }^{3}$ The sectors that were included in the study are listed in detail in the appendix.

${ }^{4}$ As Germany's largest credit rating agency, Creditreform has the most comprehensive database of German firms at its disposal. Creditreform provides data on German firms to the Centre for European Economic Research (ZEW) for research purposes.
} 
other companies and, in a further question, whether they use the Internet for ordering products and/or services from other companies. According to the OECD (1999, p. 28) the definitions of e-commerce vary between "including all financial and commercial transactions that take place electronically, including electronic data interchange (EDI), electronic funds transfers (EFT), and all credit/debit card activity", and limiting e-commerce "to retail sales to consumers for which the transaction and payment take place on open networks like the Internet". The definition of ecommerce in this study is a rather narrow one, only including the ordering and selling of products and services on the Internet. Only those firms selling their products/services via the Internet to other firms are considered as firms actively using B2B. As already mentioned, B2B e-commerce is still the most widespread application of e-commerce. Moreover, selling products/services reflects an active way of implementing (B2B) e-commerce. Firms have to build up an electronic trade platform on their server, they have to reorganize their logistics and workplaces in order to guarantee a smooth handling of orders they receive via the Internet and in order to fully explore probable efficiency gains of their e-commerce activities. ${ }^{5}$ In contrast, using the Internet only passively in the sense of buying products and/or services does not necessarily require substantial adjustments of business activities, although these firms might reduce their search and transaction costs and possibly profit from a larger market transparency.

Table 1: Use of the Internet

\begin{tabular}{l|ccc}
\hline & no use & sporadic use & broad use \\
\hline Information/communication & $7 \%$ & $42 \%$ & $51 \%$ \\
Advertising/marketing & $32 \%$ & $46 \%$ & $22 \%$ \\
B2C & $68 \%$ & $22 \%$ & $9 \%$ \\
B2B & $56 \%$ & $32 \%$ & $12 \%$ \\
Ordering products/services & $38 \%$ & $50 \%$ & $12 \%$ \\
Electronic Banking & $41 \%$ & $16 \%$ & $44 \%$ \\
Customer services & $22 \%$ & $51 \%$ & $27 \%$ \\
Recruitment & $70 \%$ & $23 \%$ & $8 \%$ \\
\hline Extrapolated Data; Source: ZEW survey, own calculations.
\end{tabular}

Table 1 shows extrapolated data on the intensity of using the Internet for various purposes. In order to take account of different intensities of Internet use, our questionnaire distinguishes between three stages of diffusion: no use, sporadic use

\footnotetext{
${ }^{5}$ The relation between the introduction of new ICTs and the need for organizational changes in the firm in order to achieve positive productivity effects is examined for instance by Bresnahan, Brynjolfsson and Hitt (2000) and is also discussed by Brynjolfsson and Hitt (2000).
} 
Table 2: B2B e-commerce by industry sectors

\begin{tabular}{|c|c|c|c|}
\hline \multirow[b]{2}{*}{ Industry } & \multicolumn{3}{|c|}{ B2B e-commerce in $\%$} \\
\hline & no use & sporadic use & broad use \\
\hline Consumer goods industry & 60.17 & 33.47 & 6.36 \\
\hline Chemical industry & 47.70 & 44.25 & 8.05 \\
\hline Other basis goods industry & 53.16 & 35.44 & 11.39 \\
\hline Mechanical engineering & 51.24 & 36.04 & 12.72 \\
\hline Electrical engineering & 40.00 & 44.39 & 15.61 \\
\hline Medical, precision and optical instruments & 52.56 & 37.21 & 10.23 \\
\hline Motor manufacturing industry & 51.11 & 36.44 & 12.44 \\
\hline Wholesale trade & 52.94 & 33.99 & 13.07 \\
\hline Retail trade & 64.40 & 26.18 & 9.42 \\
\hline Transport and post & 53.65 & 33.85 & 12.50 \\
\hline Financial intermediation & 49.09 & 40.45 & 10.45 \\
\hline Computer and telecommunication services & 32.84 & 40.67 & 26.49 \\
\hline Technical services & 54.26 & 32.29 & 13.45 \\
\hline Other business services & 58.33 & 31.37 & 10.29 \\
\hline ICT-sector & 37.32 & 40.97 & 21.70 \\
\hline
\end{tabular}

and broad use. ${ }^{6}$ Most establishments broadly use the Internet for information and communication as well as for electronic banking. B2B e-commerce in the sense of offering products or services via the Internet happens before B2C e-commerce and personnel recruitment.

Table 2 shows the intensity of B2B e-commerce by industry based on the sample that is used for the estimations in section $4.13 \%$ of all firms included in the empirical analysis say that they make broad use of B2B e-commerce, an additional $36 \%$ of the firms indicate sporadic use. $51 \%$ don't use the Internet for selling their products/services. ${ }^{78}$

As expected, the most intensive use of B2B e-commerce can be observed within the computer and telecommunication services sector, behind which comes electrical engineering. These two sectors also form the majority of the ICT-sector as defined by the OECD (2000). Moreover, the manufacturing of precision instruments and industrial process control equipment as well as specialized ICT-traders belong to the

\footnotetext{
${ }^{6}$ The distinction between these three stages of diffusion is based on the firms' own judgement.

${ }^{7} 5 \%$ of the firms even don't have access to the Internet.

${ }^{8}$ If the reduced sample used in this paper is compared to the whole sample of all firms that participated in the survey, no systematic difference in the use of B2B e-commerce is found.
} 
ICT-sector. ${ }^{9}$ Regarding the ICT-sector, almost $22 \%$ of these firms broadly carry out B2B transactions. Only $37 \%$ of the firms of the ICT-sector say that they don't use the Internet for $\mathrm{B} 2 \mathrm{~B}$ e-commerce. The diffusion of B2B e-commerce is rather low in the consumer goods industry and in the retail trade sector (including ICT traders). In the empirical analysis of section 4 , the share of firms utilizing the Internet for B2B e-commerce, computed for each two digit NACE-code ${ }^{10}$, will be used to measure the bandwagon effect described in section 2 .

Table 3: B2B e-commerce by size classes

\begin{tabular}{l|ccc}
\hline & \multicolumn{3}{|c}{ B2B e-commerce in \% } \\
Employees & no use & sporadic use & broad use \\
\hline $5-9$ & 63.41 & 26.83 & 9.76 \\
$10-19$ & 54.64 & 31.97 & 13.39 \\
$20-49$ & 56.61 & 31.84 & 11.55 \\
$50-99$ & 51.79 & 33.16 & 15.05 \\
$100-199$ & 51.41 & 35.74 & 12.85 \\
$200-499$ & 45.38 & 41.51 & 13.12 \\
$\geq 500$ & 43.18 & 44.55 & 12.27 \\
\hline \multicolumn{2}{l}{ Source: ZEW survey. }
\end{tabular}

Differentiating by size classes, table 3 shows that B2B e-commerce is more common for bigger firms. More than half of all companies that have at least 200 employees sell their products/services via the Internet, either sporadically or broadly. In contrast, only $36 \%$ of firms with less than 10 employees indicate a use of the Internet for selling their products or services.

\footnotetext{
${ }^{9} \mathrm{~A}$ detailed description of the ICT-sector is given in the appendix.

${ }^{10}$ For the NACE-codes 64 "post and telecommunications" and 74 "other business activities" the bandwagon effect will be calculated separately for each three digit NACE-code group.
} 


\section{Econometric implementation and empirical re- sults}

Due to the fact that the dependent variable of $\mathrm{B} 2 \mathrm{~B}$ adoption is observed in terms of the three categories "no use", "sporadic use" and "broad use", an ordered probit is used as the analytical framework (see for instance Davidson and MacKinnon, p. 529-530 for details). The intensity of the use of B2B e-commerce $y_{i}^{*}$ is assumed to linearly depend on a set of variables $X_{i}$ :

$$
y_{i}^{*}=X_{i} \beta+u_{i}, \quad u_{i} \sim N(0,1),
$$

with normally and identically distributed errors $u_{i}$ with mean zero and variance normalized to be one. The latent variable $y_{i}^{*}$ represents the intensity of using B2B e-commerce measured for instance as the share of sales achieved by using B2B ecommerce. However, only a discrete variable $y_{i}$ is observed taking on three possible values

$$
y_{i}= \begin{cases}0 & \text { if } y_{i}^{*}<\gamma_{1} \\ 1 & \text { if } \gamma_{1} \leq y_{i}^{*}<\gamma_{2} \\ 2 & \text { if } \gamma_{2} \leq y_{i}^{*}\end{cases}
$$

where $\gamma_{1}$ and $\gamma_{2}$ are two threshold parameters that have to be estimated together with the parameter vector $\beta$. In the present example, $y_{i}$ takes the value 0 if no $\mathrm{B} 2 \mathrm{~B}$ e-commerce is applied, the value 1 if a firm uses B2B sporadically and finally the value 2 if $\mathrm{B} 2 \mathrm{~B}$ is broadly used. The only restriction imposed on $\gamma_{1}, \gamma_{2}$ is that $\gamma_{2}$ has to be larger than $\gamma_{1}$. The matrix $X_{i}$ contains the explanatory variables as derived from the theoretical literature in section 2. Firm size is measured by the logarithm of the number of employees. The age of the firm is a variable with three categories taking the value one if the firm is three years old and younger, the value two if the age is between four and seven years, and the value three if the firm is older than seven years. This categorization is plausible since empirical studies for instance by Prantl (2001) show that hazard functions of young firms reach a first local maximum approximately three years after formation and a second local maximum after approximately seven years. Having survived seven years, the hazard rates stay on a comparably low level such that those firms can be regarded as "old" firms. A firm's export activity is captured by the share of sales obtained by exports (export quota). Furthermore, the share of employees having a degree from a university or from a university of applied science is considered as a measure of the firms' human capital. Firms' openness to new ICT applications is represented by the number of ICT specialists as a share of all employees and by the proportion of the firm's workforce predominantly working at a PC or a workstation. Finally, a dummy variable for a firm being part of a group of companies as well as industry dummy variables are included in the estimation. 
The estimation results are given in Table 4 . Tables 9 to 12 in the appendix report marginal effects of the exogenous variables in $X_{i}$ on the probability that a firm $i$ chooses the category "no use of B2B e-commerce" and on the probability that the category "broad use" is chosen by firm $i$, respectively. Note that marginal effects are not equal to the estimated parameter vector $\hat{\beta}$ from equation 1 . However, the marginal effects can easily be calculated according to

$$
\frac{\partial \operatorname{Prob}[y=0]}{\partial \bar{X}}=-\phi\left(\gamma_{1}-\bar{X} \beta\right) \beta
$$

and

$$
\frac{\partial \operatorname{Prob}[y=2]}{\partial \bar{X}}=\phi\left(\gamma_{2}-\bar{X} \beta\right) \beta,
$$

with $\phi(\cdot)$ as the density function of the normal distribution and $\bar{X}$ as the means of the independent variables. The marginal effect of the middle category ("sporadic use") is the difference between the value zero and the two other categories since the sum of the marginal effects with respect to all categories have to sum up to zero.

The share of high-skilled employees, i.e. employees having a degree from university (including universities of applied sciences) turns out to have a significant, but at the same time rather small marginal effect on a firm's decision to use B2B ecommerce. As hypothesized, a firm with a better educated workforce decides to use B2B e-commerce more intensively. However, when including the two variables that represent firm's openness to new ICT applications, the share of workforce working predominantly at PC and the share of ICT specialists, the variable "share of high-skilled employees" becomes insignificant, whereas the other two variables show significant effects (specification 2). In this case, we are faced with a collinearity problem. As the correlation matrix (Table 8 in the appendix) shows, the pairwise correlations between the three variables "share of workforce working predominantly at PC", "share of ICT specialists" and "share of high-skilled employees" vary between 0.4240 and 0.5464 , indicating quite a high positive correlation. The positive correlation between the variable "share of high-skilled employees" and the number of ICT specialists as a share of all employees can be explained by the fact that a high proportion of all ICT specialists has a university degree. From our survey we know that almost $60 \%$ of the ICT specialists in Germany are graduates from universities or universities of applied sciences. Therefore, additional ICT specialists in a firm simultaneously increase the share of employees having a university degree. Thus, one may conclude that firms with a knowledge intensive production process are more likely to use B2B e-commerce intensively.

Firm size has a positive and significant effect on the probability of engaging in B2B, in the sense that larger firms are more likely to adopt B2B e-commerce than smaller firms. This result is in line with the hypothesis that larger firms are able to bear 
the risk of implementing a new technology. Further, we find merely weak evidence for an effect of firm age. The categorical variable for the firm's age, distinguishing between different stages of the firm's life cycle, is significant only in specification 1 and only at the $10 \%$-level. Thus, there is no persuasive support for the hypothesis that younger firms can more easily adopt the new technology B2B e-commerce due to their higher flexibility, unconventionality or a higher readiness to take risks. Similarly, the data give no hint that firms being member of a larger group have a higher or lower inclination for utilizing the Internet for B2B e-commerce.

Concerning firms' export quota, a firm faced with international competition is more likely to engage in B2B. However, although significant, the marginal effect of the export quota is quite low. It should be noted in this context that our sample includes many firms especially from the service sector that do not export anything. While about $75 \%$ of all firms in our sample that belong to the manufacturing sector said that they exported in 1999, almost $80 \%$ of all service firms report no exports. Only $5 \%$ of all financial intermediaries and slightly more than $10 \%$ of business service firms exported in the year $1999 .{ }^{11}$ Restricting the estimations to the manufacturing sector, does not change the results, however: The export quota is still significant and the marginal effect on the probabilities stays low.

Electronic data interchange (EDI) can be regarded as a precursor of B2B e-commerce. In contrast to B2B, which is only at an early stage of its diffusion process, EDI is probably already at the end. As mentioned in section 2, it is not clear a priori whether the impact of EDI on B2B-adoption is positive or negative. To examine this effect, we include a dummy variable in the regression equation that takes the value 1 if firm $i$ uses EDI and the value 0 otherwise. Since EDI is a kind of precursor of $\mathrm{B} 2 \mathrm{~B}$, the decision to introduce EDI should have been made before the firm decides about the introduction of $\mathrm{B} 2 \mathrm{~B}$, such that there does not seem to be a problem of simultaneous decisions here. The results of this enriched regression are documented in Table 4, specification 3 and Table 11. Indeed, our results show that firms which use EDI are less likely to choose the alternative "no use of B2B e-commerce" and, consequently, are more likely to decide on a broad use of B2B e-commerce. ${ }^{12}$ Moreover, nearly all results discussed in the context of specifications 1 and 2, i.e. without the inclusion of a dummy variable for the use of EDI, stay valid. The only excep-

\footnotetext{
${ }^{11}$ These figures are based on the firms' own information. Using the definitions of the System of National Accounts, the reported export quotas of many firms would be different. For example, every sale of a retailer to a foreigner, maybe a tourist, accounts for export of a retail trade service according to the official definitions. Transactions like this are, however, not very likely to be considered by firms when answering to the question whether they export or not.

${ }^{12}$ We only have information on whether or not firms make use of EDI at the time of the interview. However, firms may have already replaced their EDI applications by e-commerce transactions, no longer utilizing the EDI technology. If it was known, additionally, which firms used EDI in the past, our reported results should become even more clear-cut.
} 
tion is the effect of the export quota which becomes insignificant when the dummy variable for the use of EDI is included, which is an unexpected and peculiar result. The problem with specification 3 is that we generally aim to discover characteristics of firms that use B2B e-commerce, whether sporadically or broadly, and that distinguish these firms from firms that don't use B2B e-commerce. However, EDI and $\mathrm{B} 2 \mathrm{~B}$ can both be interpreted as a process innovation in the ICT context. Identifying characteristics that can explain the adoption of an ICT technology should explain both the use of EDI and of B2B. Nevertheless, if we know that a firm uses EDI, it will contribute to predict whether or not this firm also uses B2B e-commerce.

In specification 4, we add the industry-wide share of firms using B2B e-commerce, based on the data of the ZEW survey, reflecting the bandwagon effect. Not only is the bandwagon effect highly significant at the 1\%-level, but the estimated marginal effects are quite high as well. If the share of firms using the Internet to sell products/services increases in the industry of firm $i$, this will lower the probability of firm $i$ opting for the alternative "no use of B2B e-commerce" (Table 12). On the other hand, the probability that firm $i$ will use B2B e-commerce "broadly" will rise. Obviously, in an industry where $\mathrm{B} 2 \mathrm{~B}$ e-commerce is already widely used, an individual firm tends to imitate its rivals and is likely to introduce B2B e-commerce as well. If it is true that $\mathrm{B} 2 \mathrm{~B}$ e-commerce reduces transaction costs as stated for example by Garicano and Kaplan $(2000)^{13}$, the individual firm will have a strong incentive to use B2B e-commerce in order not to fall behind its competitors. Observing its rivals, e.g. by carrying out benchmark analysis, a firm might be convinced of engaging in e-business itself if a high number of its rivals has introduced B2B e-commerce in the near past.

However, one restriction has to be made on this interpretation: The data of our survey only tells us, whether firm $i$ makes use of B2B e-commerce broadly, sporadically or not at all. We don't have any information about when firm $i$ started its e-commerce activities. This means, our sample probably includes firms that began with sales of products/services via the Internet just the day before the interview as well as those firms which belong to the very early adopters of this new technology. For the latter type of firms, the interpretation of the bandwagon effect does not hold. Early adopters are, by definition, not confronted with a greater or lesser bandwagon effect because they are first movers. The decision of early adopters cannot be explained by a bandwagon effect. ${ }^{14}$ Quite the reverse, the early adopters

\footnotetext{
${ }^{13}$ The possible reduction of transaction costs as a consequence of the introduction of B2B ecommerce cannot be analysed by the data of our survey.

${ }^{14}$ At least not, if we define the bandwagon effect on the level of the firm's own industry. However, it is still possible that the decision of a firm is influenced by technological developments in other sectors. Such an intersectoral spillover effect may be plausible between the software industry and technical services, but also the influence of the software industry on highly technical manufacturing sectors seems possible.
} 
themselves constitute the elements of the bandwagon effect for subsequent users of B2B e-commerce. These two sides of the same coin cannot be distinguished within our data set. However, we can argue that, except for the very first users, a relatively high proportion of firms that use the Internet for selling products/services at the time of the interview is also linked with a relatively high proportion in the past. Therefore, our definition of the bandwagon effect can represent, at least approximately, the influence of the proportion of firms in the industry who have already adopted B2B e-commerce in the near past - except, as already mentioned, for the very first users of e-commerce.

Most of included dummies representing sector-specific influences are insignificant. Only the dummy variable representing the ICT-sector is significant in specifications 1 to 3 . When controlling for the bandwagon effect (specification 4), however, the dummy variable for the ICT-sector becomes insignificant and the dummy variable for the manufacturing industry without all those firms belonging to the ICT-sector turns out to be significant, although only on the 10\%-level. Obviously, the dummy variable for the ICT-sector is a measure of a firm's ICT-intensity and covers at least partly the bandwagon effect in the first three specifications since, as shown in Table 2, the companies of the ICT-sector most frequently and most intensively use B2B ecommerce. ${ }^{15}$ Including the bandwagon effect, the results for the dummy variable for the manufacturing industry without those firms belonging to the ICT-sector indicate that the "traditional" industrial sector, often called the "old economy", makes use of $\mathrm{B} 2 \mathrm{~B}$ e-commerce to a lower extent than the service sector and the ICT-sector. However, a Wald-test for joint significance of the four sector dummies cannot reject the Null hypothesis that they are jointly zero in specification 4.

Finally, this leads to the question, how well our empirical model fits with the data. Using McFadden's $R^{2}$ as a measurement of the goodness of fit, we see that the explanatory power of our model is rather low that is, however, not unusual when using cross-sectional data. For specification 1 a value for $R^{2}$ of 0.0210 is calculated. By including the dummy variable for EDI the value of McFadden's $R^{2}$ increases to 0.0371 due to the predictive power of this dummy variable. The inclusion of the bandwagon effect only leads to an $R^{2}$ of 0.0355 in specification 4 .

\section{Concluding Remarks}

This paper studies the determinants of firms' adoption of B2B e-commerce - an Internet application that is still at the beginning of its diffusion process. An ordered

\footnotetext{
${ }^{15}$ Note that the firms of the sector computer and telecommunication services completely belong to the ICT-sector.
} 
probit model is estimated for a sample of about 3,000 firms in the German manufacturing industry and selected service sectors in the year 2000 . We can validate several hypotheses proposed in the theoretical and empirical literature on technology adoption and diffusion. The share of a firm's workforce having a degree from university positively affects firm's B2B use. Alternatively we can use in the estimations the share of a firm's workforce working predominantly at a PC or the share of ICT specialists. Each of this three variables can serve as a proxy for a knowledge-intensive production process within a firm. Moreover, we find positive and significant effects of the firm size. Thus, as proposed in the literature, large firms are more likely to adopt a new technology than small firms. There is no evidence for any significant effect of a dummy variable indicating whether or not a firm belongs to a group of companies and at best weak evidence for a significant effect of firm age. These two variables, as measures of flexibility, do not seem to play an important role in the decision to use B2B. International competition measured by the export quota of firm $i$ enhances the probability of using $\mathrm{B} 2 \mathrm{~B}$, a result that is plausible since firms faced with (international) competitive pressure have to perform efficiently in order to stay competitive. A firm's use of EDI as a precursor of B2B increases the probability to use B2B broadly. The most significant effect on a firm's decision to use B2B is the so-called bandwagon effect. The more firms in the particular industry of a firm that already use B2B e-commerce, the higher the probability that an individual firm will decide to use B2B broadly.

One crucial shortcoming of our analysis is due to the fact that it is based on a cross-sectional data set. Since we do not know anything about the year when a firm started using $\mathrm{B} 2 \mathrm{~B}$, we cannot model the diffusion of $\mathrm{B} 2 \mathrm{~B}$ as time proceeds. However, data on the use of new ICTs or especially on the use of e-commerce is still scarce. Although of a cross-sectional nature, our data represents one of the most comprehensive information bases on the diffusion of new ICT applications in German industry. 


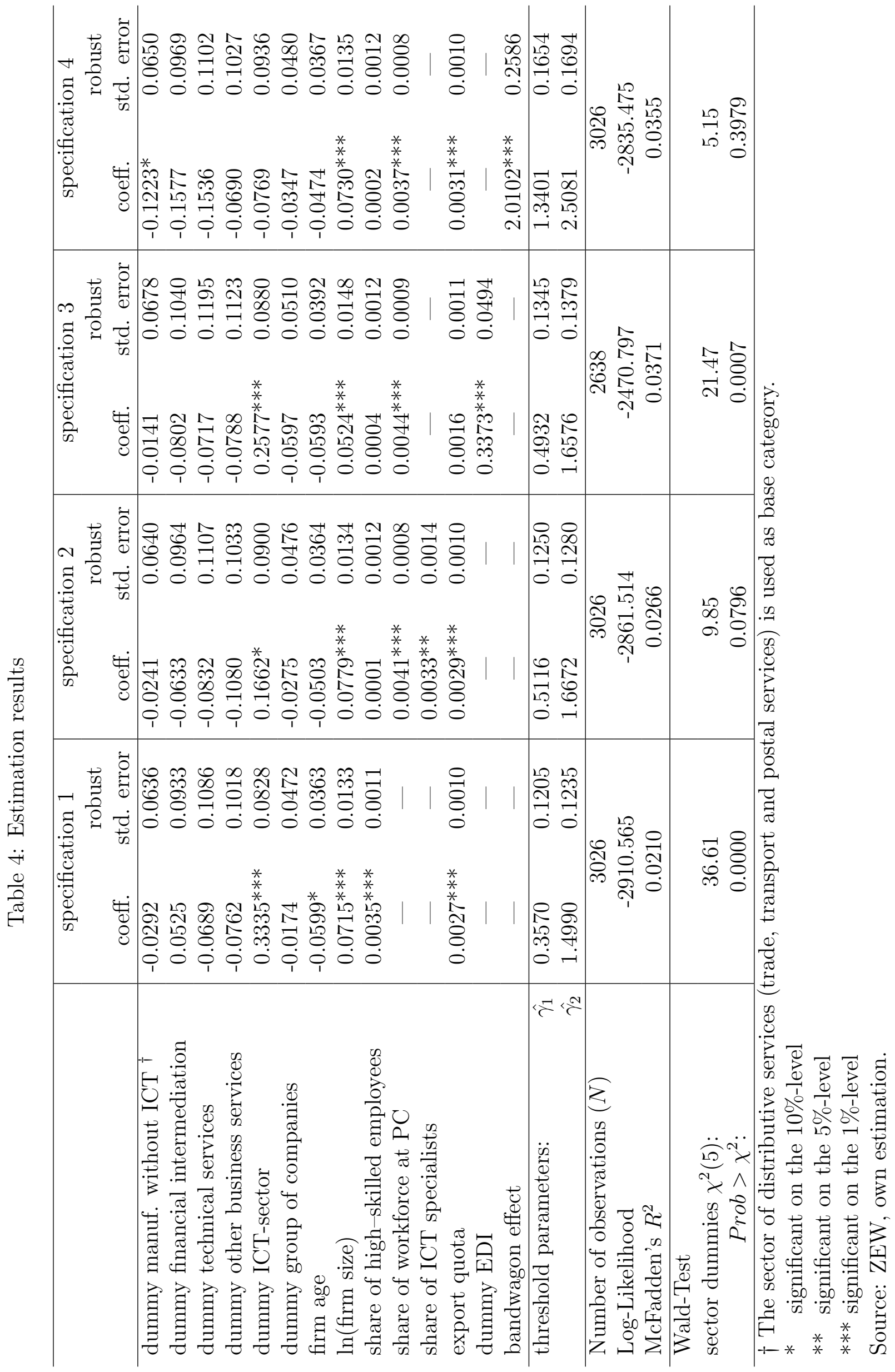




\section{Appendix}

Table 5: Sectors considered in the sample

\begin{tabular}{l|c}
\hline Industry & NACE-Code \\
\hline Consumer goods industry & $15-22,36,37$ \\
Chemical industry & 23,24 \\
Other basis goods industry & 25,26 \\
Mechanical engineering & 28,29 \\
Electrical engineering & $30-32$ \\
Medical, precision and optical instruments & 33 \\
Motor manufacturing industry & 34,35 \\
Wholesale trade & 51 \\
Retail trade & 50,52 \\
Transport and post & $60-63,64.1$ \\
Financial intermediation & $65-67$ \\
Computer and telecommunication services & $64.2,72$ \\
Technical services & $73,74.2,74.3$ \\
Other business services & $70,71,74.1,74.4-74.8,90$ \\
\hline Own classification.
\end{tabular}


Table 6: Definition of the ICT-sector according to the OECD

\begin{tabular}{l|c}
\hline Industry & NACE-Code \\
\hline Manuf. of office machinery and computers & 30.0 \\
Manuf. of insulated wire and cable & 31.3 \\
Manuf. of electronic values, tubes and & 32.1 \\
$\begin{array}{l}\text { other electronic components } \\
\text { Manuf. of telev. and radio transmitters and apparatus }\end{array}$ & 32.2 \\
$\begin{array}{l}\text { for line telephony and line telegraphy } \\
\text { Manuf. of television and radio receivers, sound or video }\end{array}$ & 32.3 \\
recording or reproducing apparatus and associated goods & \\
Manuf. of instruments and appliances for measuring, & 33.2 \\
checking, testing, navigating and other purposes & \\
Manuf. of industrial process control equipment & 33.3 \\
$\begin{array}{l}\text { Wholesale of radio and TV goods } \\
\text { Wholesale of office machinery }\end{array}$ & 51.43 .3 \\
Retail sale of radio and TV goods ${ }^{\dagger}$ & 52.64 .1 \\
Retail sale of optical and photographic & 52.48 .4 \\
goods, computers and software ${ }^{\dagger}$ & \\
Telecommunications & 64.2 \\
Renting of office machinery and & 71.33 \\
equipment including computers & 72 \\
Computer and related activities &
\end{tabular}

$\dagger$ Not included in the definition of the OECD (2000, p. 249).

Source: OECD (2000), own classification.

Table 7: Descriptive statistics of exogenous variables

\begin{tabular}{l|ccccc}
\hline & mean & median & minimum & maximum & stand. deviation \\
\hline firm age & 30.67 & 15 & 1 & 315 & 30.67 \\
bandwagon effect & 0.490 & 0.482 & 0.200 & 0.833 & 0.105 \\
ln(firm size) & 4.599 & 4.437 & 1.609 & 12.32 & 1.823 \\
share of high-skilled employees & 23.51 & 13 & 0 & 100 & 25.09 \\
share of ICT specialists & 9.331 & 1.200 & 0 & 100 & 23.37 \\
share of employees, & 47.44 & 40 & 0 & 100 & 32.67 \\
working predominantly at PCs & & & & & \\
export quota & 15.40 & 0 & 0 & 100 & 23.59 \\
\hline
\end{tabular}


Table 8: Matrix of pairwise correlations

\begin{tabular}{|c|c|c|c|c|c|c|c|}
\hline & firm age & $\begin{array}{c}\text { bandwagon } \\
\text { effect }\end{array}$ & $\ln ($ firm size $)$ & $\begin{array}{c}\text { share of } \\
\text { high-skilled } \\
\text { employees }\end{array}$ & $\begin{array}{c}\text { share of } \\
\text { ICT } \\
\text { specialists }\end{array}$ & $\begin{array}{c}\text { share of } \\
\text { workforce } \\
\text { at PC }\end{array}$ & $\begin{array}{r}\text { export } \\
\text { quota }\end{array}$ \\
\hline firm age & 1.0000 & -0.0984 & 0.2565 & -0.1819 & -0.1436 & -0.1175 & 0.1080 \\
\hline bandwagon effect & & 1.0000 & 0.0058 & 0.3011 & 0.4682 & 0.3278 & 0.0486 \\
\hline $\ln ($ firm size $)$ & & & 1.0000 & -0.0933 & -0.1268 & -0.1054 & 0.2681 \\
\hline share of high-skilled employees & & & & 1.0000 & 0.4398 & 0.5464 & -0.0300 \\
\hline share of ICT specialists & & & & & 1.0000 & 0.4240 & -0.0782 \\
\hline share of workforce at PC & & & & & & 1.0000 & -0.0741 \\
\hline export quota & & & & & & & 1.0000 \\
\hline
\end{tabular}


Table 9: Estimation results - marginal effects, specification 1

\begin{tabular}{|c|c|c|c|c|}
\hline & \multicolumn{2}{|c|}{$\begin{array}{c}\text { marginal effects } \\
\text { for } y=0, " \text { no use" } \\
\text { robust }\end{array}$} & $\begin{array}{r}\mathrm{m} \\
\text { for } y\end{array}$ & $\begin{array}{l}\text { al effects } \\
\text { "broad use" } \\
\text { robust } \\
\text { stand. error }\end{array}$ \\
\hline dummy manuf. without ICT ${ }^{\dagger \ddagger}$ & 0.0117 & 0.0253 & -0.0058 & 0.0126 \\
\hline dummy financial intermediation ${ }^{\dagger}$ & -0.0209 & 0.0372 & 0.0107 & 0.0195 \\
\hline dummy technical services ${ }^{\dagger}$ & 0.0274 & 0.0431 & -0.0132 & 0.0201 \\
\hline dummy other business services ${ }^{\dagger}$ & 0.0303 & 0.0404 & -0.0145 & 0.0186 \\
\hline dummy ICT-sector ${ }^{\dagger}$ & $-0.1321^{* * *}$ & 0.0325 & $0.0752^{* * *}$ & 0.0210 \\
\hline dummy group of companies ${ }^{\dagger}$ & 0.0069 & 0.0188 & -0.0034 & 0.0093 \\
\hline firm age & $0.0239^{*}$ & 0.0145 & $-0.0119^{*}$ & 0.0072 \\
\hline $\ln ($ firm size $)$ & $-0.0285^{* * *}$ & 0.0053 & $0.0142^{* * *}$ & 0.0026 \\
\hline share of high-skilled employees & $-0.0014^{* * *}$ & 0.0004 & $0.0007 * * *$ & 0.0002 \\
\hline export quota & $-0.0011^{* * *}$ & 0.0004 & $0.0005^{* * *}$ & 0.0002 \\
\hline
\end{tabular}

$\dagger$ Discrete change of dummy variable from 0 to 1.

$\ddagger$ The sector of distributive services (trade, transport and postal services) is used as base category.

$* \quad$ significant on the $10 \%$-level

** significant on the $5 \%$-level

$* * *$ significant on the $1 \%$-level

Source: ZEW, own estimation. 
Table 10: Estimation results - marginal effects, specification 2

\begin{tabular}{|c|c|c|c|c|}
\hline & \multicolumn{2}{|c|}{$\begin{array}{c}\text { marginal effects } \\
\text { for } y=0, " \text { no use" } \\
\text { robust }\end{array}$} & $\begin{array}{r}\mathrm{m} \\
\text { for } y\end{array}$ & $\begin{array}{l}\text { al effects } \\
\text { "broad use" } \\
\text { robust } \\
\text { stand. error }\end{array}$ \\
\hline dummy manuf. without ICT ${ }^{\dagger \ddagger}$ & 0.0096 & 0.0255 & -0.0048 & 0.0126 \\
\hline dummy financial intermediation ${ }^{\dagger}$ & 0.0252 & 0.0384 & -0.0121 & 0.0179 \\
\hline dummy technical services ${ }^{\dagger}$ & 0.0331 & 0.0440 & -0.0158 & 0.0201 \\
\hline dummy other business services ${ }^{\dagger}$ & 0.0429 & 0.0410 & -0.0202 & 0.0182 \\
\hline dummy ICT-sector ${ }^{\dagger}$ & $-0.0662^{*}$ & 0.0357 & $0.0351^{*}$ & 0.0202 \\
\hline dummy group of companies ${ }^{\dagger}$ & 0.0110 & 0.0190 & -0.0054 & 0.0094 \\
\hline firm age & 0.0201 & 0.0145 & -0.0099 & 0.0072 \\
\hline $\ln ($ firm size $)$ & $-0.0311^{* * *}$ & 0.0054 & $0.0154^{* * *}$ & 0.0027 \\
\hline share of high-skilled employees & -0.0000 & 0.0005 & 0.0000 & 0.0002 \\
\hline share of ICT specialists & $-0.0013^{* *}$ & 0.0005 & $0.0006^{* *}$ & 0.0003 \\
\hline share of workforce at PC & $-0.0016^{* * *}$ & 0.0003 & $0.0008^{* * *}$ & 0.0002 \\
\hline export quota & $-0.0012^{* * *}$ & 0.0004 & $0.0006^{* * *}$ & 0.0002 \\
\hline
\end{tabular}

$\dagger$ Discrete change of dummy variable from 0 to 1.

$\ddagger$ The sector of distributive services (trade, transport and postal services) is used as base category.

* significant on the $10 \%$-level

** significant on the 5\%-level

*** significant on the $1 \%$-level

Source: ZEW, own estimation. 
Table 11: Estimation results - marginal effects, specification 3

\begin{tabular}{|c|c|c|c|c|}
\hline & \multicolumn{2}{|c|}{$\begin{array}{c}\text { marginal effects } \\
\text { for } y=0, " \text { no use" } \\
\text { robust }\end{array}$} & $\begin{array}{l}\mathrm{m} \\
\text { for } y\end{array}$ & $\begin{array}{l}\text { al effects } \\
\text { "broad use" } \\
\text { robust } \\
\text { stand. error }\end{array}$ \\
\hline dummy manuf. without ICT ${ }^{\dagger \ddagger}$ & 0.0056 & 0.0271 & -0.0027 & 0.0132 \\
\hline dummy financial intermediation ${ }^{\dagger}$ & 0.0319 & 0.0413 & -0.0150 & 0.0187 \\
\hline dummy technical services ${ }^{\dagger}$ & 0.0285 & 0.0475 & -0.0135 & 0.0216 \\
\hline dummy other business services ${ }^{\dagger}$ & 0.0314 & 0.0446 & -0.0148 & 0.0201 \\
\hline dummy ICT-sector ${ }^{\dagger}$ & $-0.1023^{* * *}$ & 0.0347 & $0.0557^{* * *}$ & 0.0209 \\
\hline dummy group of companies ${ }^{\dagger}$ & 0.0238 & 0.0203 & -0.0116 & 0.0098 \\
\hline firm age & 0.0237 & 0.0156 & -0.0116 & 0.0077 \\
\hline dummy EDI ${ }^{\dagger}$ & $-0.1339^{* * *}$ & 0.0194 & $0.0673^{* * *}$ & 0.0100 \\
\hline $\ln ($ firm size $)$ & $-0.0209^{* * *}$ & 0.0059 & $0.0102^{* * *}$ & 0.0029 \\
\hline share of high-skilled employees & -0.0001 & 0.0005 & 0.0001 & 0.0002 \\
\hline share of workforce at PC & $-0.0017^{* * *}$ & 0.0004 & $0.0009^{* * *}$ & 0.0002 \\
\hline export quota & -0.0006 & 0.0004 & 0.0003 & 0.0002 \\
\hline
\end{tabular}

$\dagger$ Discrete change of dummy variable from 0 to 1.

$\ddagger$ The sector of distributive services (trade, transport and postal services) is used as base category.

* significant on the $10 \%$-level

** significant on the 5\%-level

$* * *$ significant on the $1 \%$-level

Source: ZEW, own estimation. 
Table 12: Estimation results - marginal effects, specification 4

\begin{tabular}{|c|c|c|c|c|}
\hline & \multicolumn{2}{|c|}{$\begin{array}{c}\text { marginal effects } \\
\text { for } y=0, " \text { no use" } \\
\text { robust }\end{array}$} & $\begin{array}{r}\mathrm{m} \\
\text { for } y \\
\partial y / \partial x\end{array}$ & $\begin{array}{l}\text { al effects } \\
\text { "broad use" } \\
\text { robust } \\
\text { stand. error }\end{array}$ \\
\hline dummy manuf. without ICT $^{\dagger \ddagger}$ & $0.0487^{*}$ & 0.0259 & $-0.0236^{*}$ & 0.0125 \\
\hline dummy financial intermediation ${ }^{\dagger}$ & 0.0625 & 0.0382 & $-0.0282^{*}$ & 0.0160 \\
\hline dummy technical services ${ }^{\dagger}$ & 0.0609 & 0.0434 & -0.0275 & 0.0182 \\
\hline dummy other business services ${ }^{\dagger}$ & 0.0275 & 0.0408 & -0.0129 & 0.0185 \\
\hline dummy ICT-sector ${ }^{\dagger}$ & 0.0306 & 0.0372 & -0.0145 & 0.0171 \\
\hline dummy group of companies ${ }^{\dagger}$ & 0.0138 & 0.0191 & -0.0067 & 0.0093 \\
\hline firm age & 0.0189 & 0.0146 & -0.0092 & 0.0071 \\
\hline $\ln ($ firm size $)$ & $-0.0291 * * *$ & 0.0054 & $0.0142^{* * *}$ & 0.0026 \\
\hline share of high-skilled employees & -0.0001 & 0.0005 & 0.0000 & 0.0002 \\
\hline share of workforce at PC & $-0.0015^{* * *}$ & 0.0003 & $0.0007^{* * *}$ & 0.0002 \\
\hline export quota & $-0.0013^{* * *}$ & 0.0004 & $0.0006^{* * *}$ & 0.0002 \\
\hline bandwagon effect & $-0.8016^{* * *}$ & 0.1031 & $0.3905^{* * *}$ & 0.0507 \\
\hline \multicolumn{5}{|c|}{$\dagger$ Discrete change of dummy variable from 0 to 1.} \\
\hline \multicolumn{5}{|c|}{$\begin{array}{l}\text { † The sector of distributive services (trade, transport and postal services) is used as base category. } \\
* \quad \text { significant on the } 10 \% \text {-level }\end{array}$} \\
\hline \multicolumn{5}{|l|}{ ** significant on the $5 \%$-level } \\
\hline \multicolumn{5}{|l|}{$* * *$ significant on the $1 \%$-level } \\
\hline Source: ZEW, own estimation. & & & & \\
\hline
\end{tabular}




\section{References}

Baptista, R. (2000). Do innovations diffuse faster within georgraphical clusters?, International Journal of Industrial Organisation 18: 515-535.

Bertschek, I. (1995). Product and process innovation as a response to increasing imports and foreign direct investment, Journal of Industrial Economics 43(4): 341-357.

Bresnahan, T. F., Brynjolfsson, E. and Hitt, L. M. (2000). Information technology, workplace organization and the demand for skilled labor: Firm-level evidence, Quarterly Journal of Economics, forthcoming 7136: 1-43.

Brynjolfsson, E. and Hitt, L. (2000). Beyond computation: Information technology, organizational transformation and business performance, Journal of Economic Perspectives 14(4): 23-48.

Christensen, C. M. and Rosenbloom, R. S. (1995). Explaining the attackers advantage: technological paradigms, organizational dynamics, and the value network, Research Policy 24: 233-257.

Cohen, W. M. and Levin, R. C. (1989). Empirical studies of innovation and market structure, in R. Schmalensee and R. D. Willig (eds), Handbook of Industrial Organization, Vol. II, chap. 18, Elsevier Science Publishers B.V, New York.

David, P. (1969). A contribution to the theory of diffusion, Mimeo, Stanford University.

David, P. (1975). The mechanization of reaping in the ante-bellum midwest, in D. P. (ed.), Technical Change, Innovation and Economic Growth, Cambridge University Press, Cambridge, MA.

Davidson, R. and MacKinnon, J. G. (1993). Estimation and Inference in Econometrics, Oxford University Press, Oxford.

Davies, S. (1979). The Diffusion of Process Innovations, Cambridge University Press, Cambridge, MA.

DIHT and mediamit (2000). E-business in Deutschland, Report, Deutscher Industrieund Handelstag and MediaMit GmbH.

Garicano, L. and Kaplan, S. N. (2000). The effects of business-to-business ecommerce on transaction costs, Working Paper 8017, National Bureau of Economic Research, Cambridge, MA.

Gault, F. (2000). E-commerce and business use of the internet. The Daily, Thursday, August 10, 2000.

Geroski, P. A. (2000). Models of technology diffusion, Research Policy 29: 603-625. 
Gruber, H. and Verboven, F. (2001). The diffusion of mobile telecommunications services in the european union, European Economic Review 45: 577-588.

Jensen, R. (1982). Adoption and diffusion of an innovation of uncertain profitability, Journal of Economic Theory 27: 182-193.

Karshenas, M. and Stoneman, P. (1995). Technological diffusion, in P. Stoneman (ed.), Handbook of the Economics of Innovation and Technological Change, Blackwell Publishers Ltd., Oxford, pp. 265-297.

Lucking-Reiley, D. and Spulber, D. F. (2001). Business-to-business electronic commerce, Journal of Economic Perspectives 15(1): 55-68.

Mazon, C. and Pereira, P. (2001). Electronic commerce, consumer search and retailing cost reduction, Mimeo, University Carlos III of Madrid, Spain.

OECD (1999). The economic and social impact of electronic commerce, Report, OECD, Paris.

OECD (2000). Information Technology Outlook, OECD, Paris.

Prantl, S. (2001). Financial distress, liquidations and subsidization of young firms, Dissertation, University of Mannheim, Germany.

Thirtle, C. G. and Ruttan, V. W. (1994). The Role of Demand and Supply in the Generation and Diffusion of Technical Change, Harwood Academic Publishers. 2nd printing.

Tirole, J. (1988). The Theory of Industrial Organization, MIT Press, Cambridge, MA.

Wozniak, G. D. (1987). Human capital, information, and the early adoption of new technology, The Journal of Human Resources 22(1): 101-112. 